\title{
ГЛАВА ІV
}

\section{УДК 691.5}

\section{ВОЗВЕДЕНИЕ ЗДАНИЙ И СООРУЖЕНИЙ \\ С ПОМОЩЬЮ АДДИТИВНЫХ ТЕХНОЛОГИЙ}

\author{
Колесников Александр Георгиевич \\ к.т.н., доцент
}

ФГОУ ВО «Юго-западный государственный университет»

\begin{abstract}
Аннотация: рассматриваются технологии возведения зданий и сооружений с помощью аддитивных технологий. Приводятся результаты эксперементов Пподбора состав смеси для строительного 3D принтера. У учётом особенностей возведения различных конструкций, предлагается модификация экструдера строительного 3D принтера, позволяющая оперативно менять состав смеси. Приводится сравнительный анализ материалов арматурных изделий, для целей автоматизированного и программируемого производства на строительной площадке. Предлагается конструкция строительного 3D принтера, включающая автоматическое армирование конструкций.
\end{abstract}

Ключевые слова: аддитивные технологии, строительный 3D принтер, экструдер, бетонная конструкция, композитная арматура, автоматический механизм армирования.

\section{CONSTRUCTION OF BUILDINGS AND STRUCTURES USING ADDITIVE TECHNOLOGIES}

\section{Kolesnikov Alexander Georgievich}

\begin{abstract}
The article discusses the construction of buildings and structures using additive technologies. The results of experiments on the composition selection of the mixture for a 3D building printer are presented. The invention proposes a modification of the building 3D printer extruder, which better meets the requirements of the mixture.

Comparative analysis of reinforcement products materials is given for the purposes of automated and programmable production at the construction site.
\end{abstract}


Proposed structure of building 3D printer includes automatic reinforcement of structures.

Key words: additive technologies, building 3D printer, extruder, concrete structure, composite reinforcement, automatic reinforcement mechanism.

Современные технологические процессы возведения зданий и сооружений становятся всё более автоматизированными. При этом строительная отрасль по этому показателю отстаёт от других.

Одним из решений данной проблемы является использование аддитивных технологий, которые уже получили распространение в современной практике строительства. Использовать строительные 3D принтеры и сопутствующие им компоненты можно для различных направлений строительства: от создания малых архитектурных форм и отдельных конструкций до возведения целых пролётов здания и зданий целиком [1, с.66, 2, с.157].

Современные аддитивные технологии привлекают всё больше государственных и частных инвестиций, что обусловлено их явными преимуществами: повышенным уровнем автоматизации строительных процессов, снижением времени изготовления конструкций и деталей, улучшением качества продукции, возможности моделирования с помощью CAD и BIM технологий, сокращением объемов отходов производства [3, с.58].

Анализ возведённых объектов показал, что за одно и то же время строительный 3D принтер может возводить объекты различной этажности и площади [4, с.894]. Это говорит о том, что ключевым фактором является не только конструкция самого принтера, но и характеристики строительной смеси, используемой в нем, способ введения добавок и скорость устройства арматурного каркаса.

Существующие модели 3D-принтеров в качестве основного строительного материала используют бетонную смесь, которая путём продавливания (экструзии) вязкого расплава материала или густой пасты через формующее отверстие выкладывается горизонтально на ранее выложенный принтером слой.

Наиболее распространённым материалом является бетонная или цементно-песчаная смесь с различными добавками.

Так же получил распространение ABS-пластик. Он представляет собой ударопрочную термопластическую техническую смолу. Высокие физические и механические свойства этого материала дают возможность его применения для создания различных конструкций, к которым предъявляются повышенные 
требования по прочности и износостойкости. Основными недостатками ABSпластика можно считать относительно низкую устойчивость к прямому воздействию солнечного света и значительно более высокую стоимость, чем у бетона. Готовые детали часто получаются смазанными, из-за чего нуждаются в корректировочных и восстановительных работах [5].

Скорость схватывания высокопрочных бетонных и цементно-песчаных смесей, применяемых для 3D - печати довольно велика - до 2-4 часов. Это качество является основным недостатком для изготовления высоких элементов и конструкций. Для достижения необходимой несущей способности слоёв для дальнейшего наращивания приходится периодически просушивать изделие, что значительно уменьшает скорость печати и увеличивает затраты на производство.

Суть подбора состава бетонной или цементно-песчаной смеси на современном этапе развития аддитивных технологий сводится к определению номенклатуры и количества вводимых добавок.

Одним из наиболее перспективных направлений является добавление в бетонные и цементно-песчаные смеси геополимеров - щелочеактивированных алюмосиликатных вяжущих на основе возобновляемого техногенного сырья, например, низкокальциевых зол-уноса тепловых электростанций. При этом, используя побочные продукты промышленности помимо улучшения свойств смеси, достигаются показатели по сохранению окружающей среды, устойчивости ресурсов и решения проблем утилизации промышленных отходов.

Одними из основных составляющих геополимерного бетона или раствора являются щелочные жидкости, а также наполнители и заполнители. Наиболее подходящие щелочные жидкости для производства геополимербетона являются щелочи на основе натрия или калия. Исходные материалы, выступающие в роли заполнителей и наполнителей должны содержать в своей структуре кремний $(\mathrm{Si})$ и алюминий $(\mathrm{Al})$. Это могут быть природные материалы, такие как глина, либо микрокремнезем, летучая зола, металлургический доменный шлак [6, с. 17].

Если в бетонный или цементно-песчаный раствор добавлено жидкое стекло, время схватывания сокращается, что является важнейшим показателем для 3D принтеров. Так при содержании жидкого стекла (силиката натрия 2\%) схватывание происходит примерно через час, при содержании 5\% натрия через 38 минут [7, с.66]. При этом, добавка влияет не только на скорость схватывания, но и на процесс затвердевания. При содержании силиката натрия 
не более 3\% прочность конструкции после полного затвердевания не меняется или даже незначительно возрастает, однако если содержание силиката натрия в смеси более 4 \%, то прочность с добавкой после полного затвердевания оказывается примерно на 25\% ниже, чем без добавки. Процесс подбора количества добавки дает возможность сокращать время схватывания до оптимального, не оказывая влияния на итоговую прочность конструкции.

Для дисперсного армирования конструкций, возводимых с помощью аддитивных технологий, применяются различные волокна. Например, стекловолокно повышает сопротивление состава к трещинообразованию, делает его более пластичным и удобоукладываемым, так как именно оно воспринимает растягивающие и изгибающие напряжения.

Аналогичными свойствами обладает фиброволокно, состоящее из базальта, стали или полипропилена. Добавление фибры в бетон позволяет достичь сразу нескольких целей:

- исключение традиционного металлического армокаркаса, выигрывая тем самым в жёсткости и прочностных характеристиках конструкции, снижая её вес, сокращая расходы на устройство каркаса из стальной арматуры и снижая необходимость человеческого вмешательства в работу принтера;

- увеличение подвижности бетонной или цементно-песчаной смеси, что имеет важную роль для равномерной подачи смеси через экструдер строительного 3D-принтера;

- снижение удельного веса бетонной смеси, позволяющее сократить затраты на фундаменты зданий и сооружений;

- волокна препятствуют образованию и раскрытию трещин на поверхности схватившегося бетона.

К важнейшим свойствам фиброволокна при процессе строительной 3D печати относятся его лёгкость и увеличение пластических свойств бетонной смеси.

Волокно полипропиленовое (фибра) представлено в России под названиями фиброволокно (синтетическое, полимерное, мультифиламентное) и фибрин.

Полипропиленовые волокна улучшают свойства смеси, обеспечивают вторичное армирование, в особенности в течение первого этапа усадки (в пластичном состоянии). Эти трещины формируются в первые 24 часа после того как бетон был уложен. Эти трещины образуются в следствии того, что существующее напряжение превышает прочность бетона. Вводимые полипропиленовые волокна способны поглотить силы растяжения во время 
усадки (энергия распределяется на множество волокон), что позволяет бетону развивать ее оптимальную долгосрочную прочность (рис.1). Волокно уменьшает выделение воды посредством более эффективного контроля гидратации, тем самым снижая внутренние напряжения. Благодаря контролю за выходом воды на поверхность снижается образование трещин при пластическом оседании [8, с. 101].

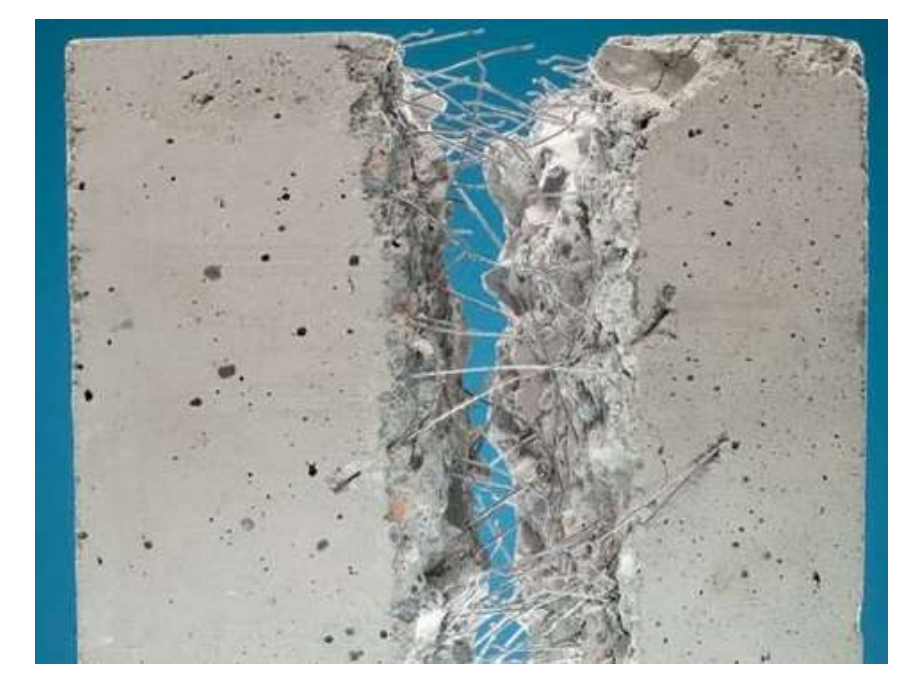

\section{Рис. 1. Характерный вид разрушения бетонных изделий, выполненных с добавлением фиброволокна}

Технологии 3D печати из смесей с добавлением фиброволокна являются перспективным направлением развития строительства, переход на этот материал позволит развивать переработку промышленных отходов, сокращать время возведения сооружений, экономить средства и повысить автоматизацию процесса [47].

Следующим направлением развития смесей для $3 \mathrm{D}$ принтеров, применяемых в строительстве, это добавление в смесь пластифицирующих добавок.

По принципу действия пластификаторы подразделяются на два вида:

- гидрофильные;

- гидрофобизующие.

Главной функцией гидрофильных пластификаторов является повышение пластичных и текучих характеристик бетона.

Гидрофобизующие пластификаторы насыщают бетонную или цементопесчаную смесь большим количеством воздуха. Таким образом, удается снизить натяжение влаги в растворе, при этом пластичные характеристики 
раствора увеличиваются [9, с. 314].

Главным преимуществом использования пластификаторов является повышение пластичности готового бетонного раствора, что очень важно для процесса прохождения смеси через экструдер строительного 3D принтера.

Добавление пластификаторов даёт возможность некоторой экономии цементного раствора. При этом, если сравнивать раствор, приготовленный без добавления пластификаторов и с ними, то количество цемента, используемое во втором случае, можно снизить на $15-17 \%$.

Уложенная смесь не нуждается в дополнительном уплотнении, так как пластификаторы делают его пластичным и прочным. При этом, удается сэкономить время и сделать процесс укладки более автономным.

С помощью добавления пластификатора удается получить раствор, который обладает высоким уровнем плотности. У конструкций, сооруженных с помощью такого раствора присутствует высокая влагонепроницаемость и морозостойкость.

Пластификаторы различают по виду образующего материала:

- органического происхождения;

- органоминеральные вещества;

- неорганические вещества.

Пластификаторы органического происхождения содержат в составе отходы нефтяной, деревоперерабатывающей промышленности или агрохимии [55].

Добавки неорганического происхождения содержат в своем составе разного рода химические вещества в виде формальдегидов или нафтасульфиткислот.

В зависимости от принципа действия, пластификаторы для бетонных и цементно-песчаных смесей разделяют на несколько видов (табл.1).

Таблица 1

Виды пластификаторов для бетонных и цементно-песчаных смесей

\begin{tabular}{|l|l|}
\hline Вид пластификатора & Эффект от введения пластификатора в смесь \\
\hline $\begin{array}{l}\text { Модифицирующие } \\
\text { вещества }\end{array}$ & $\begin{array}{l}\text { Увеличивают прочностные характеристики, } \\
\text { стойкость к коррозии, морозостойкость, уровень } \\
\text { подвижности, уменьшают паропроницаемость. }\end{array}$ \\
\hline $\begin{array}{l}\text { Вещества, ускоряющие } \\
\text { набор прочности }\end{array}$ & Уменьшают срок набора прочности растворов \\
\hline
\end{tabular}




\begin{tabular}{|l|l|}
\hline Суперпластификаторы & $\begin{array}{l}\text { Высокая подвижность бетонного или цементно- } \\
\text { песчаного состава, с одновременным увеличением } \\
\text { влагонепроницаемости, эластичности и прочности. } \\
\text { Снижается расход цемента в составе раствора. }\end{array}$ \\
\hline $\begin{array}{l}\text { Вещества, } \\
\text { добавляющие воздух в } \\
\text { состав смеси }\end{array}$ & $\begin{array}{l}\text { Добавки в составе бетонной или цементно-песчаной } \\
\text { смеси, делают её микропористой и весьма }\end{array}$ \\
\hline $\begin{array}{l}\text { Добавки } \\
\text { самоуплотняющегося } \\
\text { состава }\end{array}$ & С их помощью удается произвести заливку \\
\hline
\end{tabular}

Наиболее распространёнными являются суперпластификаторы, которые позволяют получить высокоподвижные смеси, снизить трудозатраты на обработку и кладку, снижают количество воды в смеси, повышают степень реагирования цемента, прочность и долговечность изделий. Позволяет получить литые смеси без расслоения и водоотделения. Современные составы суперпластификаторов адаптированы к различным заполнителям и цементам, в том числе к шлакощелочным, с содержанием шлаков до $80 \%$.

Расход зависит от требуемого уровня подвижности смеси, качества и чистоты используемых в замесе материалов.

Для определения более точных результатов по расходу добавки необходимо проводить предварительные контрольные замесы, исходя из текущих условий окружающей среды по влажности, содержанию цемента в сухой смеси, качества и влажности песка и инертных заполнителей.

На рисунке 2 показан характер разрушения стандартных образцов из цементно-песчаной смеси без добавок (рис.2,a), образцов с добавлением пластификаторов и фиброволокна (рис.2,б) и образцов с добавлением пластификатора, отвердителя и фиброволокна (рис.2,в). 

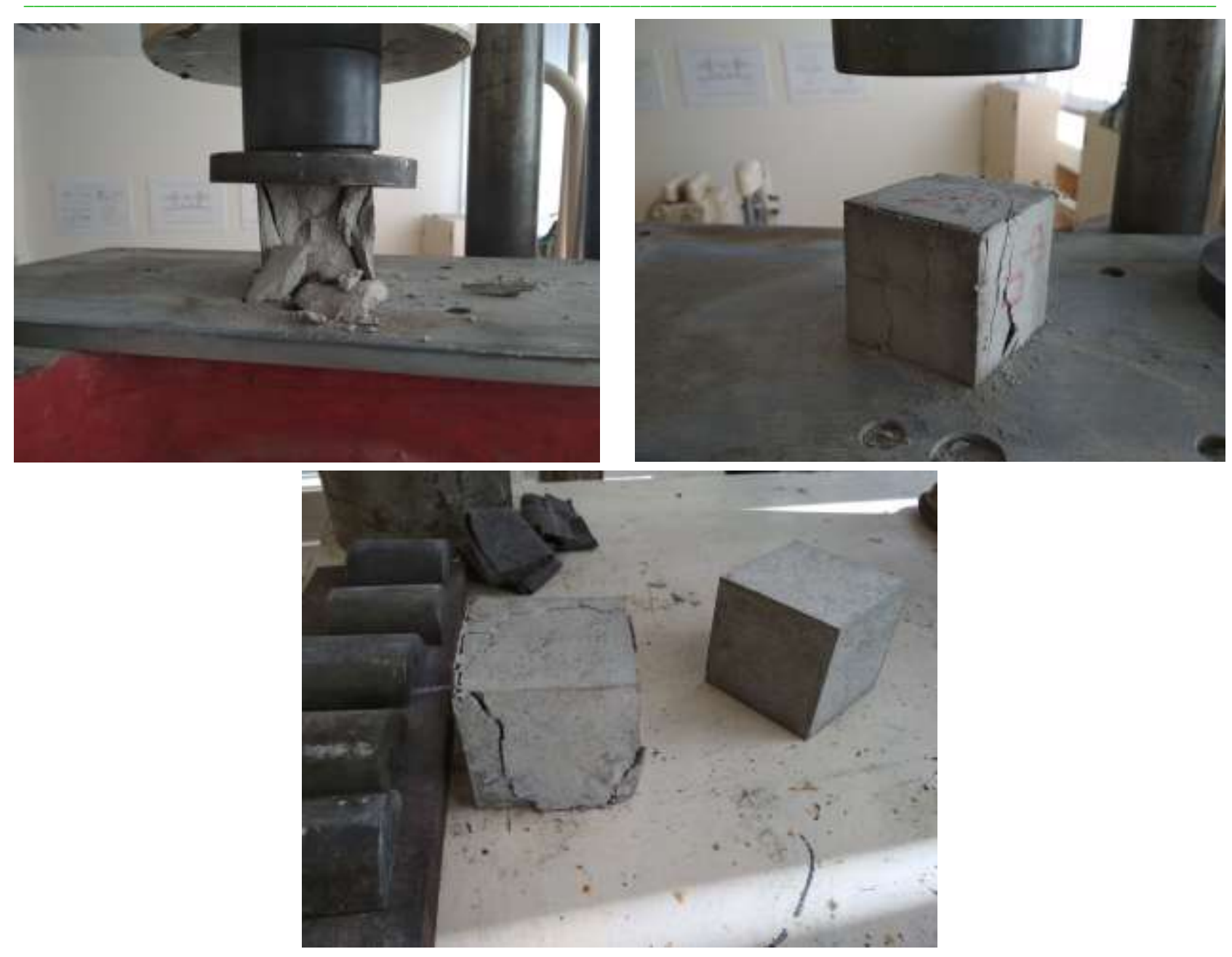

Рис. 2. Характер разрушения образцов из цементно-песчаной смеси:

а) без добавок, б) образцов с добавлением пластификаторов и фиброволокна, в) образцов с добавлением пластификатора, отвердителя и фиброволокна до и после начала испытаний

Для определения необходимого состава и отношения ингредиентов смеси [5-8], обеспечивающих оптимальную работу 3D строительного принтера были проведены испытания на определение предела прочности образцов на сжатие в возрасте одних суток и определение удобоукладываемости смеси [9]. Удобоукладываемость смеси оценивалась показателями подвижности по погружению конуса в соответствии с ГОСТ 28013-98 [10].

Для проведения испытаний были изготовлены контрольные образцы из цементно-песчаного раствора; образцы с добавлением фиброволокна (фибра полипропиленовая 600 гр на $1 \mathrm{~m}^{3}$ ) и пластификатора (универсальная суперпластифицирующая добавка 85 л/м ${ }^{3}$; с добавлением фиброволокна, пластификатора и ускорителя твердения (1 л/100 кг цемента) [11]. Результаты 
экспериментов на удобоукладываемость для различных составов смеси приведены на рисунке 3. Результаты испытаний образцов на сжатие приведены в рисунке 4.

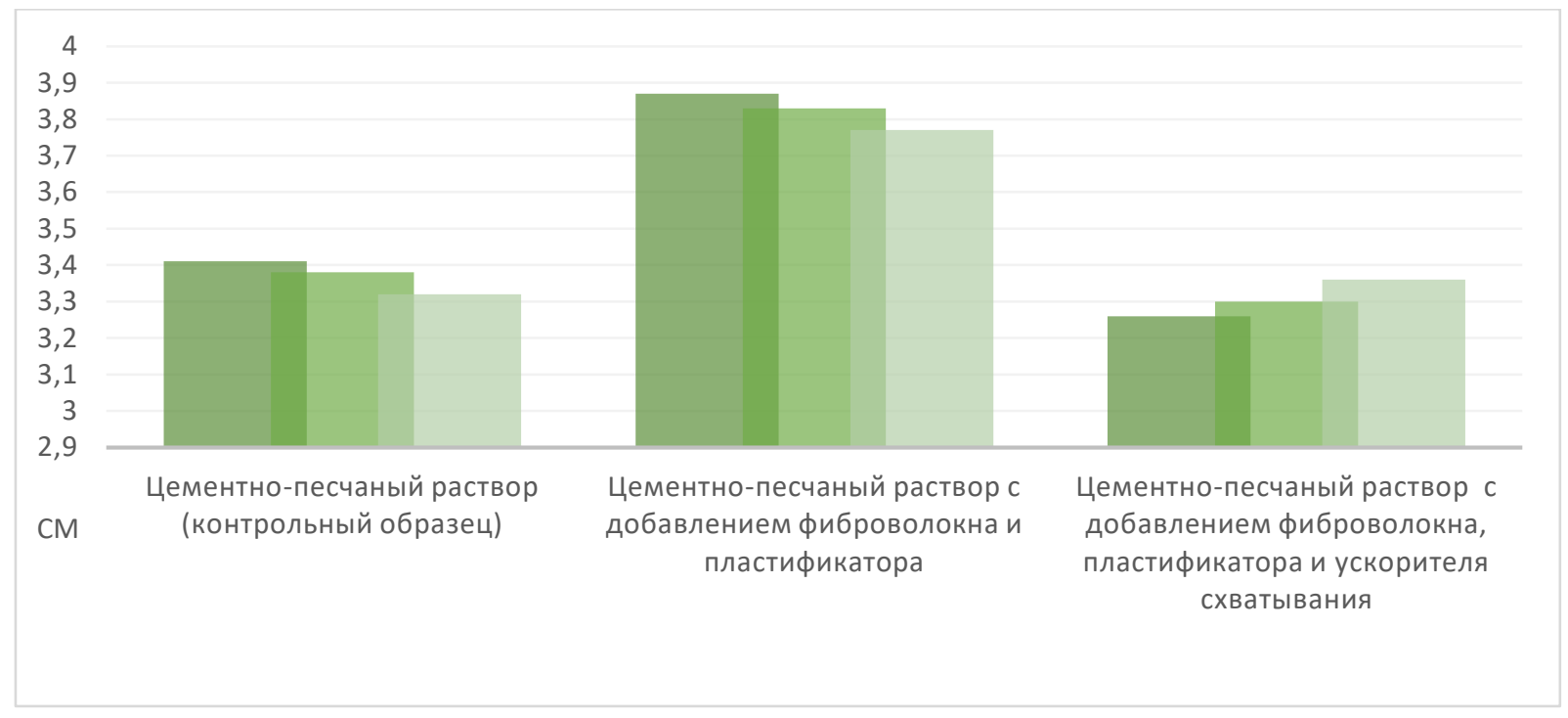

\section{Рис. 3. Результаты экспериментов различных составов смесей на удобоукладываемость}

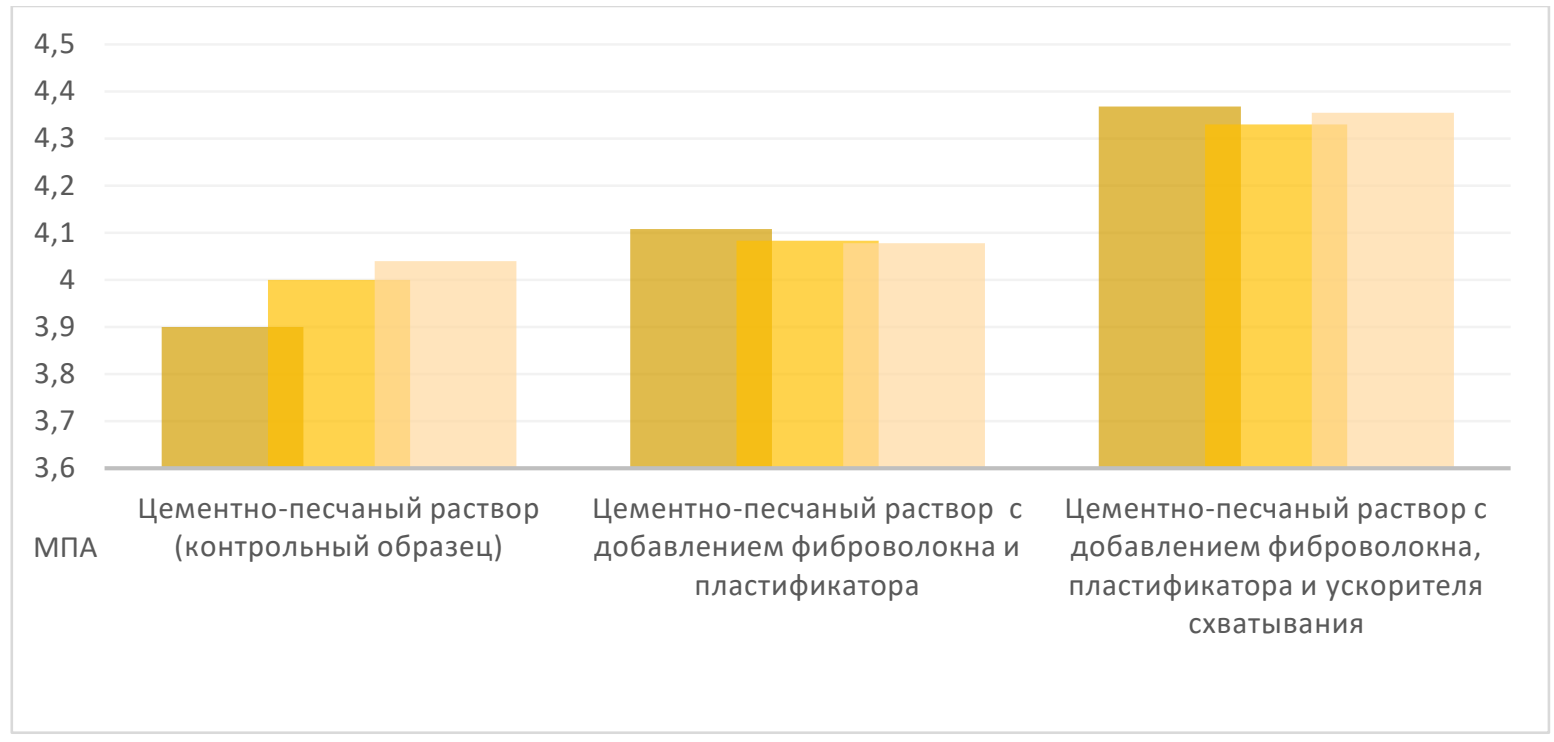

\section{Рис. 4. Результаты испытаний образцов на прочность в возрасте одних суток}

Для исследования удобства использования смесей в 3D принтере была разработана установка, имитирующая процесс экструдирования смеси. Груз на площадке загружения приводил в действие поршень внутри корпуса (цилиндра), находящаяся внутри строительная смесь выдавливалась из сопла 
[11]. Результаты испытаний смесей на удобство прохождения через сопло экструдера приведено на рисунке 5.

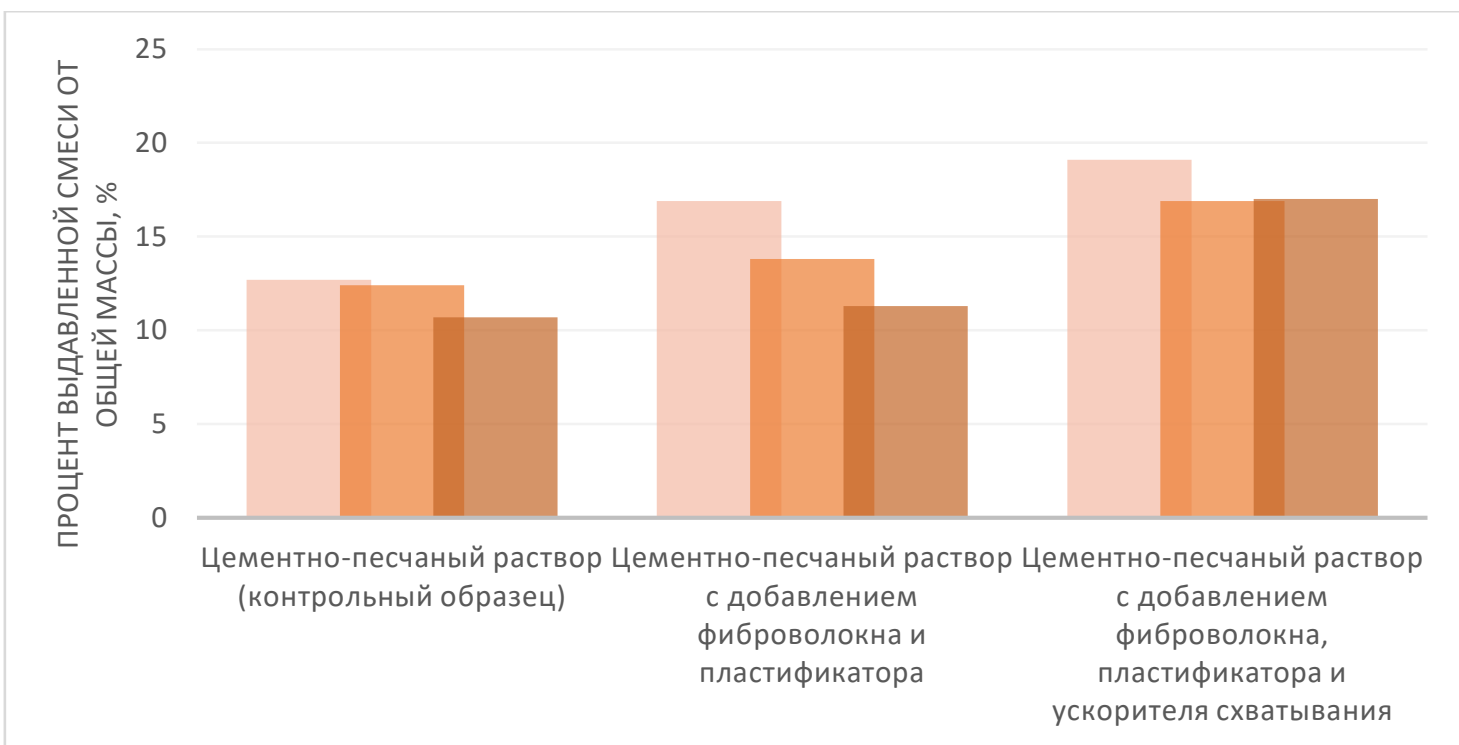

\section{Рис. 5. Результаты испытаний смесей на удобство прохождения через сопло экструдера}

B большинстве 3-D принтеров осуществляется безопалубочное формование конструкций и смеси должны быстро схватываться и держать форму. С другой стороны, в конструкциях с высоким коэффициентом армирования важны характеристики удобоукладываемости и пластичности.

Каждый участок возводимого строительным 3D принтером здания или сооружения необходимо рассматривать как частный случай. В различных конструктивных элементах целесообразнее применять различные добавки и изменять процент армирования. Для этого необходима быстрая смена состава смеси строительного принтера и автоматизация процесса армирования [11].

Для быстрой смены состава смеси строительного принтера была разработана конструкция, обеспечивающая поступление добавок непосредственно перед выдавливанием строительного раствора [12]. Это способствует уменьшению времени прохода смеси через 3D принтер и дает возможность порциально менять состав (рис.6)

На приводе механизма подачи смеси установлен механизм крепления, соединяющий подсоединенную к нему неподвижную трубку подачи смеси и герметичное соединение, к которому подсоединена находящаяся внутри привода механизма подачи и вращающаяся вместе с ним и шнеком трубка подачи смеси, на которой установлены форсунки подачи смеси [12]. 
Модернизированный экструдер строительного принтера состоит из печатающей головки, внутри которой при помощи двигателя привода механизма подачи смеси и привода механизма подачи смеси вращается шнек, выдавливающий строительную смесь из экструдера. На печатающей головке установлено устройство формирования поверхности, которое выравнивает экструдированную строительную смесь. На двигателе привода механизма подачи смеси установлена неподвижная трубка подачи смеси, которая соединена с вращающейся трубкой подачи смеси механизмом крепления и герметичным соединением. Вращающаяся трубка подачи смеси проходит через привод механизма подачи и крепится на оси вращения шнека. На вращающейся трубке подачи смеси установлены форсунки подачи смеси.

Вводимая в раствор добавка через неподвижную трубку подачи смеси поступает во вращающуюся трубку подачи смеси и распределяется в строительном растворе через форсунки подачи смеси (рис.6).

a)

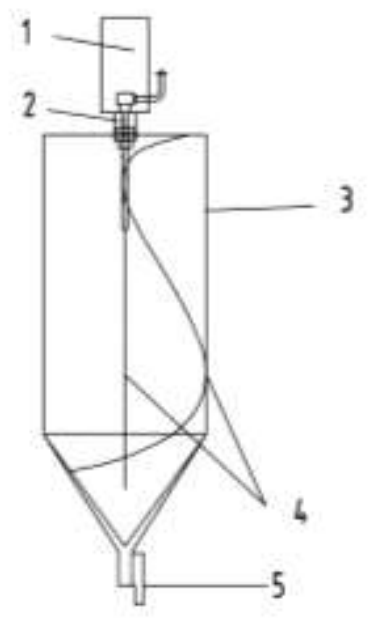

б)

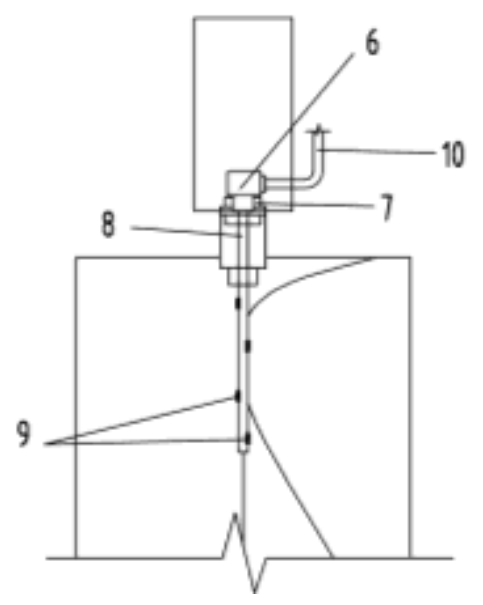

Рис. 6. Схема экструдера строительного 3D принтера:

а) общий вид, б) механизм подачи смеси

1 - двигатель привода механизма подачи смеси, 2 - привод механизма подачи смеси, 3 печатающая головка, 4 - шнек, 5 - устройство формирования поверхности, 6 - механизмом крепления, 7 - герметичное соединение, 8 - трубка подачи смеси, 9 - форсунки подачи смеси, 10 - трубка подачи смеси.

Разработанная модель позволяет производить быструю смену состава смеси строительного принтера, а также обеспечить поступление добавок непосредственно перед выдавливанием строительного раствора.

Для разработки принципов автоматизированного армирования при использовании аддитивных технологий необходимо провести анализ прочностных и эксплуатационных характеристик арматурных стержней (табл. 
2) $[13,14]$.

Помимо традиционной стальной арматуры, существует четыре наиболее распространённых вида композитной арматуры:

1) Стеклопластиковая (АСП) - производится путём смешивания стекловолокна термореактивными смолами, которые выступают в роли связующего. Отличительная особенность этого вида - высокая прочность при малом весе;

2) Базальтопластиковая (АБП). В качестве основы служит базальтовое волокно, в качестве связующего - органические смолы. Преимущество данного вида композитной арматуры - высокая стойкость к воздействию агрессивных химических сред: щелочей, кислот, газов и солей;

3) Углепластиковая (АУП) - состоящая их углеводородных волокон и ввиду высокой стоимости не получившая широкого спроса;

4) Комбинированная (АКК) - состоит одновременно из стекловолокна и волокон базальта.

Композитная арматура уже применяется в промышленном и гражданском строительстве, в малоэтажном и коттеджном строительстве в бетонных конструкциях, для слоистой кладки стен с гибкими связями, для ремонта поверхностей железобетонных и кирпичных конструкций, а также при работах в зимнее время, когда в кладочный раствор вводятся ускорители твердения и противоморозные добавки, вызывающие коррозию стальной арматуры.

Основные положительные качества композитной арматуры:

- стойкость к коррозии, невосприимчивость к воздействию влаги и агрессивных жидкостей значительно повышает долговечность конструкций;

- значительная удельная прочность (высокий предел прочности по отношению к плотности материала), превышает показатели стальной арматуры класса в $10-15$ раз;

- низкая теплопроводность - позволяет избежать появления мостиков холода в массиве конструкции;

- диэлектричность повышает электробезопасность сооружений и позволяет исключить помехи при прохождении радиоволн.

- удобство при транспортировке в виду малой массы. Композитную арматуру небольших диаметров возможно перевозить в бухтах.

Наряду с многочисленными достоинствами композитная арматура не лишена и неких недостатков, которые необходимо учитывать при проектировании армированных бетонных конструкций.

К минусам композитной арматуры относят:

- низкий модуль упругости материала. Данный параметр по сравнению со 100 
сталью меньше в 4 раза, что негативно сказывается при работе композитной арматуры на растяжение;

- хрупкость и не пластичность. Изменение формы стержня невозможно без нагрева, что создаёт трудности при изготовлении монтажных петель и закладных деталей.

- низкая стойкость к воздействию высоких температур. В отличие от стали, композитный материал теряет свои прочностные свойства уже при температурах порядка 150-300 градусов, в зависимости от вида используемых в производстве волокон (стеклопластик или базальтопластик).

Арматурные стержни в случае заливки монолитных конструкций размещаются в опалубке с определённым шагом и увязываются между собой вязальной проволокой или пластиковыми хомутами нужной длинны (рис.7). Последний вариант возможен благодаря небольшой массе прутков арматуры.

Сварка композитной арматуры невозможна ввиду диэлектрических свойств материала, сборка сеток и каркасов осуществляется одинаковым способом.

Расчёт композитной арматуры производится по тем же принципам, что и для металлической. За тем лишь исключением, что полученные при расчёте металлические прутки заменяют прутками из композитной арматуры другого диаметра с аналогичными прочностными характеристиками.
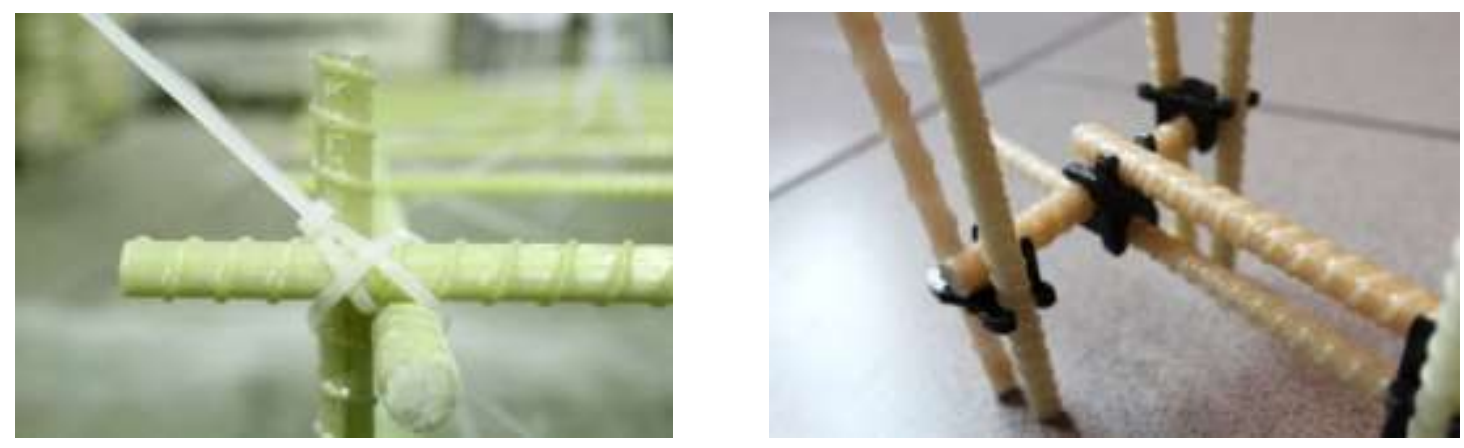

\section{Рис. 7. Крепление хомутом трех прутков композитной арматуры}

Кроме пластиковых хомутов возможно использование металлических арматурных элементов, которые выполняют функцию конструктивных элементов. Форма и вид фиксаторов обусловлены их назначением и расположением арматуры в монолитной конструкции.

Сравнительные характеристики стальной и различных видов композитной арматуры приведены в таблице 2. 
Таблица 2

Сравнение качественных характеристик стальной и композитных арматур

\begin{tabular}{|l|c|c|c|c|}
\hline & $\begin{array}{l}\text { Стекло- } \\
\text { пластиковая }\end{array}$ & $\begin{array}{l}\text { Базальто- } \\
\text { пластиковая }\end{array}$ & $\begin{array}{l}\text { Угле- } \\
\text { пластиковая }\end{array}$ & Сталь \\
\hline $\begin{array}{l}\text { Предельная } \\
\text { температура } \\
\text { эксплуатации, }\end{array}$ & 200 & 300 & 600 & 200 \\
\hline $\begin{array}{l}\text { Модуль } \\
\text { упругости, ГПа }\end{array}$ & 56 & 65 & $140-350$ & $480-690$ \\
\hline $\begin{array}{l}\text { Прочность на } \\
\text { разрыв, МПа }\end{array}$ & $480-1500$ & $800-1200$ & 1750 & 25 \\
\hline $\begin{array}{l}\text { Относительное } \\
\text { удлинение, \% }\end{array}$ & 2,2 & 3 & 1,6 & 200 \\
\hline
\end{tabular}

Из таблицы 2 видно, что из вариаций композитных арматур явное преимущество по основным критериям имеет углепластиковая арматура, но в связи с еe дороговизной, её применение в массовом строительстве нецелесообразно.

Основные отличия характеристик стеклопластиковой арматуры от базальтопластиковой - это меньшая прочность на разрыв, меньшее относительное удлинение и меньший модель упругости в стеклопластиковой арматуре. Отсюда следует, что предпочтительнее всего использовать базальтопластиковую арматуру.

Сравнивая стальную и базальтопластиковую арматуры, видно, что модуль упругости у стали выше, но в базальтопластиковой прочность на разрыв больше, нежели в стали и относительное удлинение значительно ниже, что является ее существенными плюсами.

Если рассматривать таблицу 2 и технические характеристики конкретных изделий, то вопрос о равнозначности решается в зависимости от того, в каких условиях будет эксплуатироваться конструкция из армированного бетона.

По прочности на разрыв стальная арматура в поперечном сечении 12 мм может быть заменена на стеклопластиковую 8 мм, а стальная 18 стеклопластиковой 14.

Из таблицы видно, что при возведении зданий с помощью аддитивных технологий целесообразно использовать композитную арматуру. По техникоэкономическим характеристикам наиболее предпочтительна композитная 
арматура на основе базальтовых волокон. Но для полной автоматизации процесса возведения здания необходимо модернизировать конструкцию экструдера строительного $3 \mathrm{~d}$ принтера $[15,16]$.

Существуют различные технологические линии для изготовления композитной арматуры.

Большинство линий состоит из двух блоков основного оборудования:блока подготовки и пропитки ровингов полимерным связующим [17]. Блок пропитки ровингов включает шпулярник с бобинами ровингов, выравнивающее устройство, камеру отжига, пропиточную ванну, натяжное устройство, формующее устройство, блок формирования структуры наружной поверхности арматуры. Блок формирования структуры наружной поверхности арматуры включает два узла спиральной обмотки, полимеризационные камеры, ванну охлаждения, тянущее устройство, узел резки и сматывания. Технологические линии снабжены одним или несколькими дополнительными блоками оборудования выполнения спиральных обмоток внутренних слоев арматуры. Они включают блок подготовки и пропитки ровингов полимерным связующим, устройство спиральной намотки, полимеризационную камеру. Такие линии работают с базальтовым и углепластиковым волокном.

Недостатком технологических линий изготовления стклопластиковой арматуры, основанной на фильерной технологии (метод «пултрузия»), является невозможность получения композитной арматуры с непрерывной рельефностью [18-20].

Технологические линии для изготовления композитной арматуры с различным количеством слоев стержня комплектуют из блоков различного функционального назначения.

В блоках № 1 ровинги из стеклянных, базальтовых, углеродных и прочих волокон с бобин шпулярника, количество которых определяет сердцевину или слой несущего стержня арматуры, проходят через выравнивающее устройство, разделяющее полотно ровингов на отдельные пучки, камеру отжига, удаляющую влагу при температуре $200-250^{\circ} \mathrm{C}$. Затем пучки ровингов поступают в пропиточную ванну, заполненную полимерным связующим с температурой $40-60^{\circ} \mathrm{C}$, отжимное роликовое устройство, удаляющее из волокон излишнее полимерное связующее, и поступают в формовочный узел, объединяющий пучки ровингов в сердцевину или слой арматуры.

После этого пропитанные волокна поступают в блок № 2, в котором устройство спиральной обмотки осуществляет намотку натсердцевину тонких нитей или плоских ровингов. 
Далее сердцевина арматуры с первой внутренней спиральной намоткой проходит через полимеризационную камеру, в которой осуществляется предварительный нагрев стержня до температуры $100-120^{\circ} \mathrm{C}$, и поступает в формовочный узел. В формовочном узле подготовленные и пропитанные полимерным связующим ровинги равномерно располагаются вокруг сердцевины и образуют равномерную толщину волокон второго слоя. Такое расположение оборудования обеспечивает уплотнение волокон сердцевины, осуществляет предварительный нагрев до температуры ниже температуры отверждения полимерного связующего и производит формирование второго слоя стержня из предварительно пропитанных полимерным связующим ровингов.

Для выполнения наружной структуры поверхности арматуры предварительно нагретый слоистый стержень с 2-мя внутренними спиральными обмотками поступает в устройства блока № 3. Блок № 3 в устройствах спиральной обмотки производит образование рельефной поверхности, в печи полимеризации, осуществляет, нагрев до температуры $150-250^{\circ} \mathrm{C}$ и отверждение стержня. В ванне арматуру охлаждают для предотвращения деформирования в роликах тянущего устройства. В узле резки арматуру режут на необходимую длину и сматывают в бухту [16].

Учитывая имеющийся опыт, экструдер строительного 3D принтера с механизмом армирования можно выполнить на базе печатающей головки, рассмотренной выше. Его отличие будет в том, что на печатающую головку устанавливается механизм горизонтального армирования. На рисунке 8 представлен общий вид экструдера строительного 3D принтера с механизмом армирования (рис.8, а) и механизм армирования (рис. 8, б). 

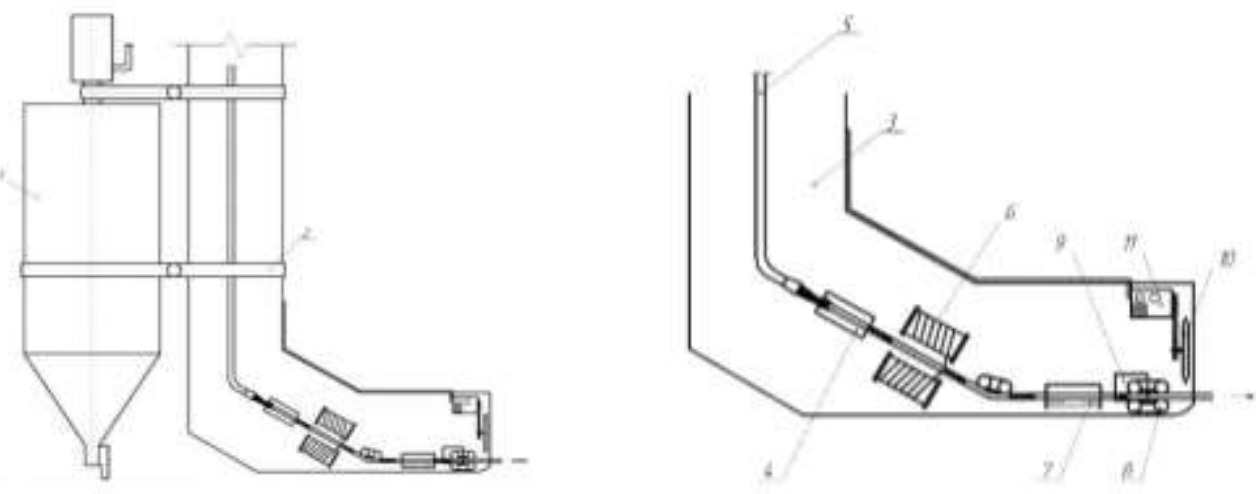

\section{Рис. 8. Экструдер строительного 3d принтера с механизмом армирования:}

а) общий вид экструдера строительного $3 \mathrm{~d}$ принтера, б) механизм армирования. 1 - экструдер, 2 - крепление, 3 - корпус, 4 - фильера, 5 - трубка подачи, 6 узел скрутки нити, 7 - ванна водяного охлаждения, 8 - устройство протяжки, 9 - двигатель устройства протяжки, 10 - устройство резки, 11 - двигатель.

Движение заготовки в механизме обеспечивает устройство протяжки. Волокна поступают через трубку подачи в нагретую фильеру для полимеризации связующих, после поступает в узел скрутки нити для придания рельефа, далее заготовка охлаждается в ванне водяного охлаждения, и нарезается по заданным размером устройством резки, которое вращается при помощи двигателя.

Использование механизма армирования в совокупности с экструдером строительного 3d-принтера, обеспечивает горизонтальное армирование по всему периметру возводимых конструкций. Это будет способствовать уменьшению ручного труда, увеличению прочностных характеристик и возможности создавать более сложные архитектурные формы.

Представленная информация результатах экспериментов исследования составов смеси, позволяет подобрать состав, наилучшим образом отвечающей требованиям, предъявляемым при использовании аддитивных технологий.

Для лучшего использования подобранной смеси при возведении различных конструкций и большей автоматизации, предложена модификация экструдера строительного 3D принтера, позволяющая порционно вводить добавки в разработанную смесь.

Представлен сравнительный анализ арматурных изделий, с рекомендациями, позволяющими применить принципы автоматизированного и программируемого производства на строительной площадке.

Предложена конструкция строительного 3D принтера, включающая 105 
автоматическое армирование конструкций.

\section{Список литературы}

1. Дребезгова М.Ю. Современные аддитивные технологии в малоэтажном строительстве // Вестник Белгородского государственного технологического университета им. В.Г. Шухова. - 2017. - № 6. - С. 66-69.

2. Лесовик В.С., Чернышева Н.В., Глаголев Е.С., Дребезгова М.Ю., Ермолаева А.Э. 3D-аддитивные технологии в сфере строительства // Интеллектуальные строительные композиты для зеленого строительства. 2016. - С. 157-167.

3. Удодов С.А., Белов Ф.А., Золотухина А. Е. 3D-печать в строительстве: новое направление в технологии бетона и сухих строительных смесей // Сб. ст. VI Международной научно-практической конференции МЦНС «Наука и просвещение». Пенза, -2017. - С. 58-62.

4. Орлов А.К., Зайченко К.В. Аддитивные технологии - будущее малоэтажного строительства // Экономика и предпринимательство. - 2017. № 10-1 (87). - C. 894-899.

5. Wolfs R., Salet T. An Optimization Strategy for 3D Concrete Printing // EGICE 2015 -22nd Workshop of the European Group of Intelligent Computing in Engineering. - 2015. Code 114260

6. Легезина А.С., Пашкова Л.А. 3d-принтер в строительстве современного жилья // Вестник Науки и Творчества. - 2018. - № 11 (35). - С. 17-19.

7. Дребезгова М.Ю. Современные аддитивные технологии в малоэтажном строительстве // Вестник Белгородского государственного технологического университета им. В.Г. Шухова. - 2017. - № 6. - С. 66-69.

8. Мухаметрахимов Р.Х., Изотов В.С. Повышение физико-механических свойств и долговечности фиброцементных плит на основе целлюлозных волокон // Известия высших учебных заведений. Строительство. - 2012. - № 9 (645). - C. 101-107.

9. Wang Yo., Wu H.C., Li V.C. Concrete reinforcement with recycled fibers // Journal of Materials in Civil Engineering, - 2000. - No. 4-12. - P. 314-319.

10. Халиуллин М.И., Алтыкис М.Г., Рахимов Р.З. Эффективные сухие гипсовые смеси с добавками полимерных волокон // Известия высших учебных заведений. Строительство. - 2004. - № 3. -С. 33-37.

11. Гувалов А.А., Кузнецова Т.В. Влияние модификатора на свойства цементных суспензий // Строительные материалы. - 2013. -№ 8. С. 86-88.

12. Несветаев Г.В., Удодов С.А., Бычкова О.А. О влиянии состава, 106 
модифицированного гипсоглиноземистого расширяющегося цемента на прочность и темп твердения // Интернет-журнал Науковедение. - 2015. - Т. 7. № 6 (31). - С. 122 .

13. Козьев А.Д., Колесников А.Г. Развитие технологии конструирования 3D-принтеров // В сборнике: Инновационные внедрения в области технических наук сборник научных трудов по итогам международной научно-практической конференции. - 2018. - С. 19-22.

14. ГОСТ 28013-98. Растворы строительные. Общие технические условия. - Введ. 1999-07-01. - М.: Стандартинформ, 1999. С. 17.

15. Колесников А.Г. Модернизация конструкции экструдера строительного 3d принтера и подбор составов для него // Урбанистика. - 2019. № 2. - С. 64-70

16. Экструдер строительного 3d принтера. Козьев А.Д., Ступишин Л.Ю., Колесников А.Г. Патент на полезную модель RU 185166 U1, 23.11.2018. Заявка № 2018133084 от 18.09.2018.

17. Пустовгар А.П., Адамцевич А.О., Волков А.А. Технология и организация аддитивного строительства // Промышленное и гражданское строительство. - 2018. - № 9. - С. 12-20.

18. Клиндух Н.Ю., Турышева Е.С., Амузин И.К., Дремин Е.С., Булес Е.Д., Воробьева Е.А. Строительный 3d-принтер манипуляторного типа // Транспортные сооружения. - 2019. - Т. 6. - № 4. - С. 13.

19. Технологическая линия для изготовления композитной арматуры. Шахов А. С., Шахов С. В., Шабалин С. И., Шабалин С. И., Лялин Е.В., Степанова В. Ф., Степанов А.Ю. Патент на полезную модель №2417889. 10.05.2011.

20. Пермяков М.Б., Пермяков А.Ф., Давыдова А.М. Аддитивные технологии в строительстве // European Research. - 2017. - № 1 (24). - C. 14-15.

(C) А.Г. Колесников, 2020 